\title{
The Radon Gas in Underground Buildings in Clay Soils. The Plaza Balmis Shelter as a Paradigm
}

\author{
Carlos Rizo Maestre * (D) and Víctor Echarri Iribarren \\ Department of Building Construction, University of Alicante, Carretera San Vicente del Raspeig, s/n, \\ 03690 San Vicente del Raspeig, Spain; victor.echarri@ua.es \\ * Correspondence: carlosrm@ua.es
}

Received: 12 April 2018; Accepted: 15 May 2018; Published: 17 May 2018

\begin{abstract}
In healthy buildings, it is considered essential to quantify air quality. One of the most fashionable indicators is radon gas. To determine the presence of this element, which is harmful to health, in the environment, the composition of the soil is studied. The presence of radon gas within a building depends both on the terrain in which it is located and on the composition of the materials of which it is composed, and not as was previously believed, only by the composition of the soil (whether granitic or not). Many countries are currently studying this phenomenon, including Spain where the building regulations regarding the accumulation of radon gas, do not list in their technical codes, the maximum dose that can a building can hold so that it is not harmful to people and the measures to correct excessive accumulation. Therefore, once the possible existence of radon in any underground building has been verified, regardless of the characteristics of the soil, the importance of defining and unifying the regulations on different levels of radon in all architectural constructions is evident. Medical and health science agencies, including the World Health Organization, consider that radon gas is a very harmful element for people. This element, in its gaseous state, is radioactive and it is present in almost soils in which buildings are implanted. Granitic type soils present higher levels of radon gas. Non-granitic soils have traditionally been considered to have very low radon levels. However, this paper demonstrates the relevant presence of radon in non-granitic soils, specifically in clayey soils, by providing the results of research carried out in the underground air raid shelter at Balmis Square in Alicante (Spain). The results of the measurements of radon accumulation in the Plaza Balmis shelter are five times higher than those obtained in a similar ungrounded building. This research addresses the constructive typology of an under-ground building and the radon presence in its interior obtained using rigorous measurement techniques.
\end{abstract}

Keywords: radon; underground building; construction materials; healthy architecture; environment; heritage construcion

\section{Introduction}

Radon gas is produced as a result of the decay of uranium contained in rocks [1]. Radon flows from the soil and is mostly concentrated in closed areas [2], so it is highly recommended that homes and workplaces are properly ventilated [3]. Three quarters of the radioactivity in the environment comes from natural elements [4]. Radon is the largest source of natural radioactivity [5] and the public health problem that its concentration generates both inside buildings and in drinking water makes it necessary to consider it for evaluation [6].

Radon decays due to so-called ionising radiation because when it penetrates matter, it usually pulls electrons from the surrounding atoms by a process known as ionisation [7]. If the matter is a biological structure with a high water content, the ionisation of water molecules can give rise to so-called free radicals with a high level of chemical activity, enough to alter important molecules that 
are part of the cells of living organisms [8]. These alterations may include chemical changes in DNA, the basic organic molecule that is part of the cells that make up our body [9]. These changes may lead to biological effects, including abnormal cell development [10]. These alterations can be more or less severe depending on the dose of radiation received [11]. The main effect of the presence of radon in the human environment is the risk of lung cancer [12]. The presence of people inside a building helps the movement of air and therefore the renovation. However, if the accumulation values are high, additional corrective actions should be taken. This radioactive gaseous element is present in almost all construction materials, and in the soil where buildings are implanted $[13,14]$. There are different radon measuring devices. Some are active, require electricity and allow a continuous record of the concentration and fluctuations of radon gas during the measurement period [15]. Others are passive and do not require electric power to operate in the sampling environment [16]. Ionic Chambers of Electretes (ICE) have been used to carry out this research. ICEs are passive devices that function as integrative detectors to measure the average radon gas concentration during the measurement period. The electret functions both as a generator of an electric field and as a sensor in the ion chamber. The radon gas enters the chamber by diffusion through an inlet equipped with a filter without allowing the rest of the elements produced during the decay process to pass through [17]. Radiation emitted by radon, and its decay products formed inside the chamber, ionise the air contained inside the chamber reducing the voltage of the detector surface [18]. Subsequently, a calibration factor relates this voltage drop to the concentration of radon in the studied space and time.

In isolated constructions, or on the ground floor of buildings, the most important source of radon is the ground. The radio concentration in the ground is generally between 10 and $50 \mathrm{~Bq} / \mathrm{m}^{3}$, although it can reach much higher values. The average value is around $40 \mathrm{~Bq} / \mathrm{m}^{3}$. The amount of radon that enters an interior from the ground depends mainly on the concentration of radium-226 in the subsoil and the permeability of the subsoil.

In most countries there are predictive maps of radon content, mainly representing the igneous composition of the soil [19-22]. For example, Sweden has developed maps based on the measurement of the geogenic potential of radon, which indicate the risk level by zone, estimated from the concentration of radon in the ground at $1 \mathrm{~m}$ depth [23-25]. Likewise, the usefulness of methods based on other variables, such as soil radio-226 concentration or uranium equivalent has also been tested. In the case of France, for example, the national map has been compiled from geological maps and average uranium content of each geological unit [25-27]. The German map [28] and the Czech map [29] have also been developed using the geogenic potential of radon. All the radon gas predictive maps consider that granitic soils are the most risky in terms of their concentrations. They consider clayey soils as having a low presence of radon gas. In Spain, in February 2018, the Technical Building Code (CTE), does not yet state the dose of radon that one building can contain at most and how to control it $[30,31]$.

The soil of the Spanish Mediterranean coast, where the city of Alicante is located, is mainly clayey [32]. The underground air raid shelter of Seneca Square is located in the city centre of Alicante (Spain). This shelter was built in 1937 during the Spanish Civil War (1936-39), and was restored in 2011 in order to be part of the city's museum tours. Different aspects of the shelter have been studied: the constructive typology of the underground building, its historical context and the presence of radon on the inside obtained through rigorous measurement techniques. By virtue of the results obtained from the measurements, the shelter serves as a paradigm to demonstrate the relevant presence of more than $100 \mathrm{~Bq} / \mathrm{m}^{3}$ of radon in the interior of an underground building in non-granitic soil [22].

\section{The Plaza Balmis Shelter. Construction and Restoration}

The Spanish Civil War took place in Spain between 1936 and 1939, where two sides, the Republicans and the rebels fought to take control of Spain [33]. The bomb shelters of the Civil War in Alicante, are a singular type of architectural construction that conserves little information because they were developed without technical documentation conditioned by the urgent need to build shelters to protect 
the population [34]. From the documents present in the Municipal Archive of Alicante (MAA), it is known that, in 1937, there were 18 shelters with capacity for 8070 people and 15 more were to be built for 9900 people. In 1938, there were 55 shelters with a capacity for 38,140 people and 37 more shelters were planned that would have provided the city with a total capacity for 108,590 people. At present, there are about 90 shelters that were built during the war.

The shelter at Doctor Balmis Square is located in the square that bears his name, Figure 1. Shelter R46, as it is known according to the authorities currently responsible for the conservation of the city of Alicante, has two accesses: one on Canalejas street and the other, at the intersection of Limones and El Cid streets. The second access is walled up, probably since the demolition of the roofs carried out by the government since 1945 .

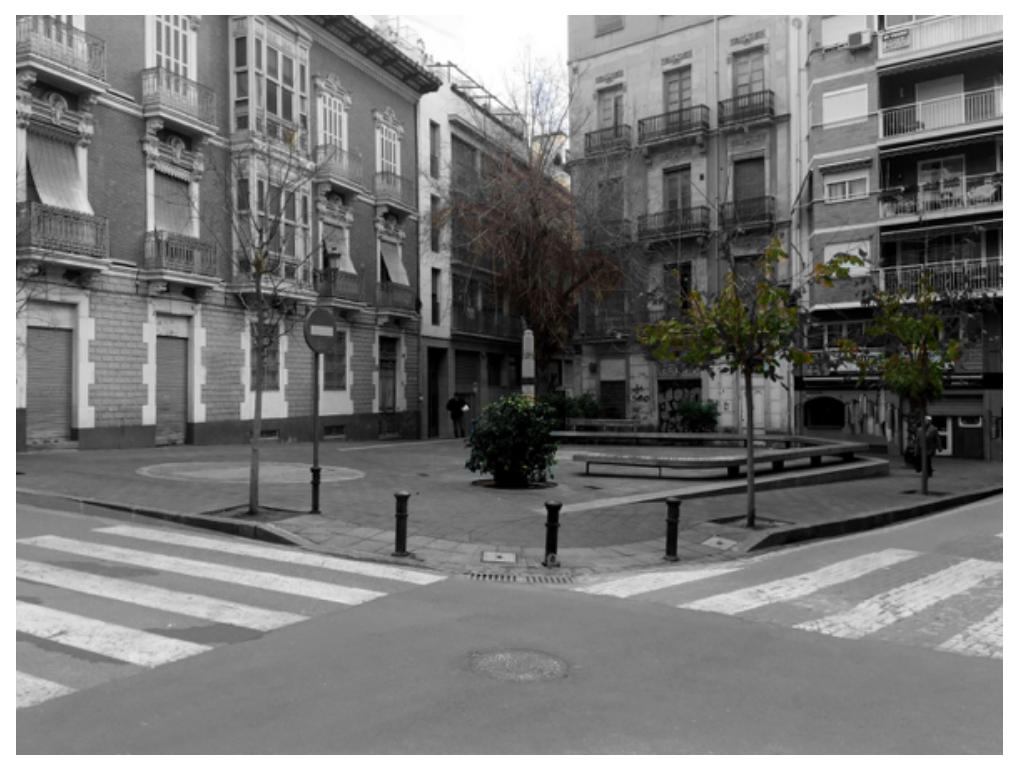

Figure 1. Doctor Balmis Square at present.

The bombardments of 1939 were devastating for the area of the square and the surroundings areas due to the siege of the city by the rebel side. In September 1945, six years after the end of the war and in the middle of Franco's dictatorship, a project was drawn up for the demolition of all the constructions on the ground floor of the streets or squares, entailing the demolition of the roofs of the shelters with these characteristics. The decision to dismantle the roofs of this type of buildings was provoked by the complaints of the neighbours due to their dilapidated state, the bad smells caused by humidity and the beginnings of deterioration by detachment.

In the years after the war, during the Franco dictatorship, the square received different treatments, and renovations were carried out that culminated in the development of the shelter by the City Council of Alicante for visitors who were interested in the history of the city in the Spanish Civil War.

The shelter at Plaza Balmis is cellular, type 3, according to the characteristics of the municipal architect of the time, the shelter's body being buried two meters below the level of the square (Figure 2). The volumetric layout of the shelter (Figure 3) is composed of six rectangular cells with a surface area of approximately $7.5 \mathrm{~m}^{2}$ in each one of them with a height ranging from $1.81 \mathrm{~m}$ to $2.33 \mathrm{~m}$. The six rooms are connected by passages of approximately $1 \mathrm{~m}$. The shelter complex has about $50 \mathrm{~m}^{2}$ without accesses. The two central partitions are connected to the accesses and serve as a distribution for the other four that consisted of a stone bench. The galleries are separated by walls of $0.60 \mathrm{~m}$ width, made of cement mortar masonry and plaster up to half height. The lateral chambers are separated from the two central chambers by rings that brace the structure in its lower part and reinforce the upper part with semi-circular arches lower than those used in the vaults. 


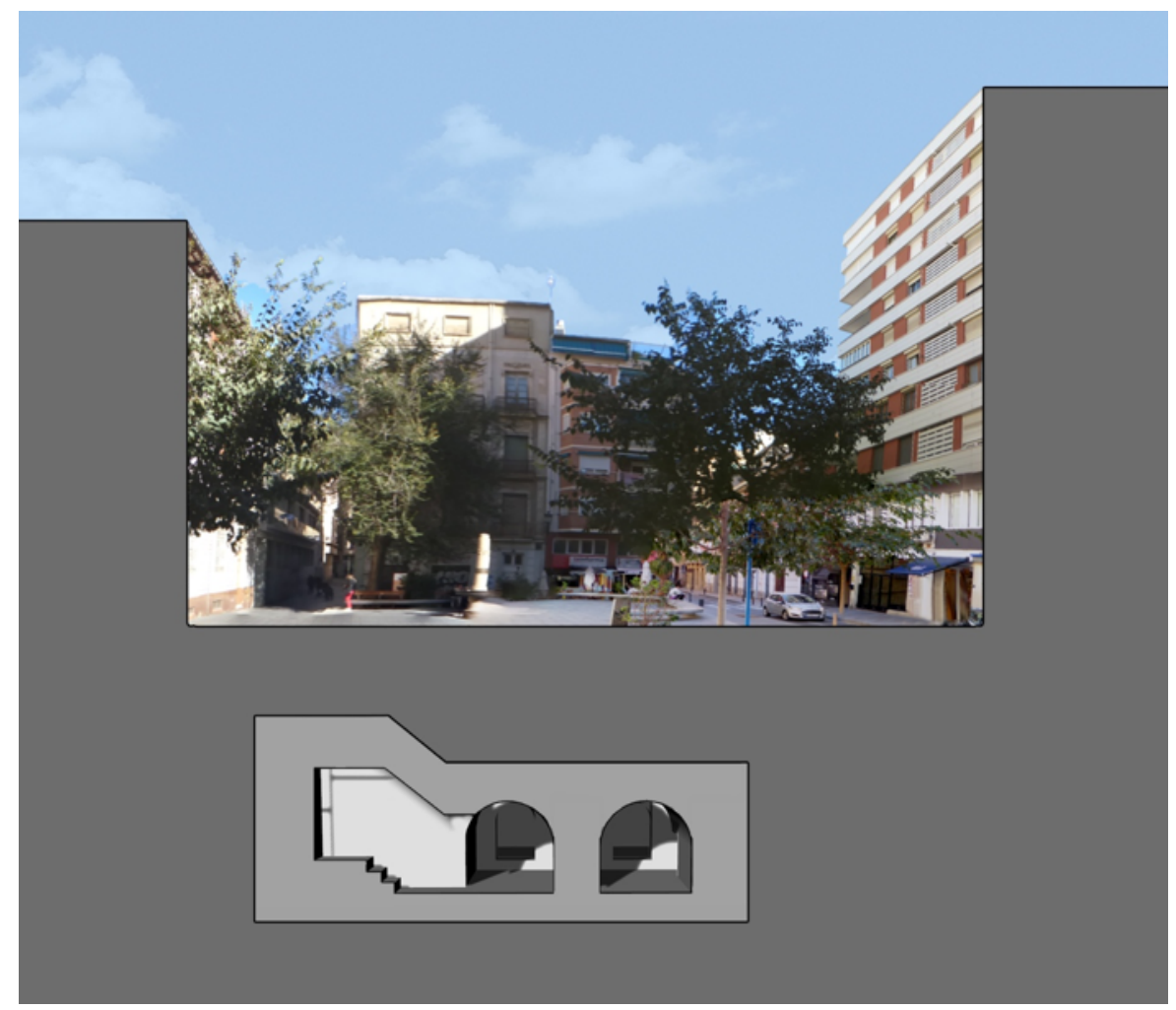

Figure 2. Photomontage of the Plaza Balmis section in its current state.

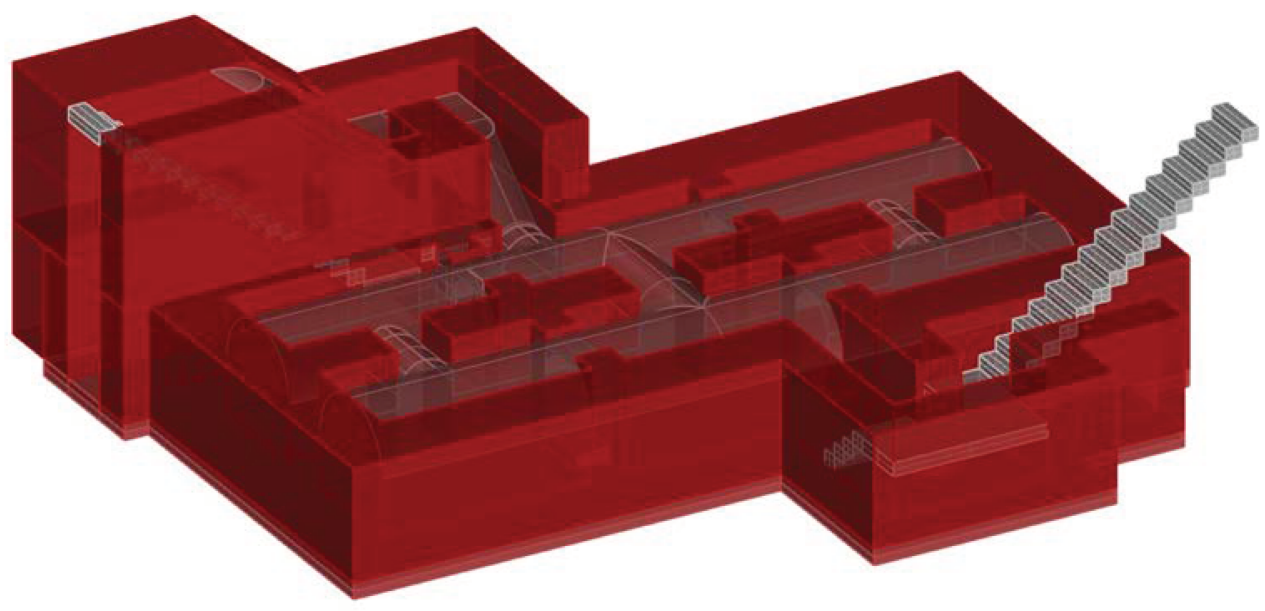

Figure 3. Image of the volumetry of the refuge of Plaza Balmis where the two entrances are shown. The right corresponds to that of the streets Limones and Cid, currently walled and the left corresponds to the only entrance available. The vaulted roofs are shown in a lowered semicircular arch. In the upper part there is a large concrete layer of up to $1.5 \mathrm{~m}$, this side being the most protected.

The construction, as shown in the Figures 4 and 5 has two zigzag accesses at the end of each stairway, to attenuate the effects of the shock waves caused by the bombs and in the event that one of them was not usable, the other was the escape route for the occupants of the shelter. The entrances are built on a base of mass concrete that serves as a support for the stairways built with hollow brick. The interior access to the square, corresponding to the intersections of Limones and Cid streets, is currently covered due to different developments that have been carried out in the square. The walled access was probably filled with rubble from the roof demolition carried out in 1946. 

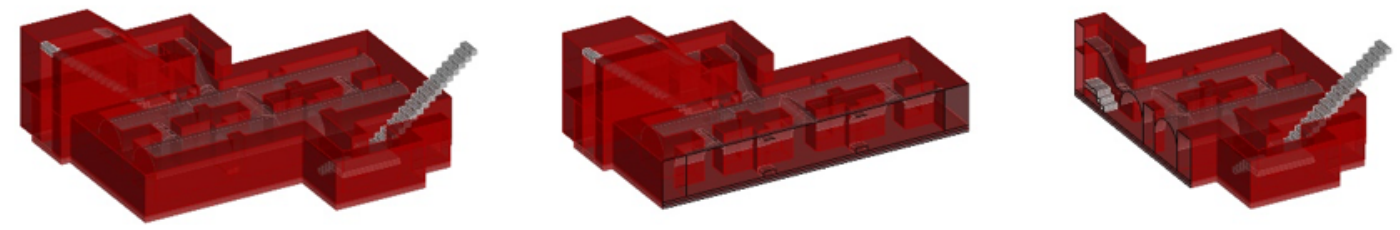

Figure 4. 3D reconstruction images of the refuge, showing cross sections in both directions.
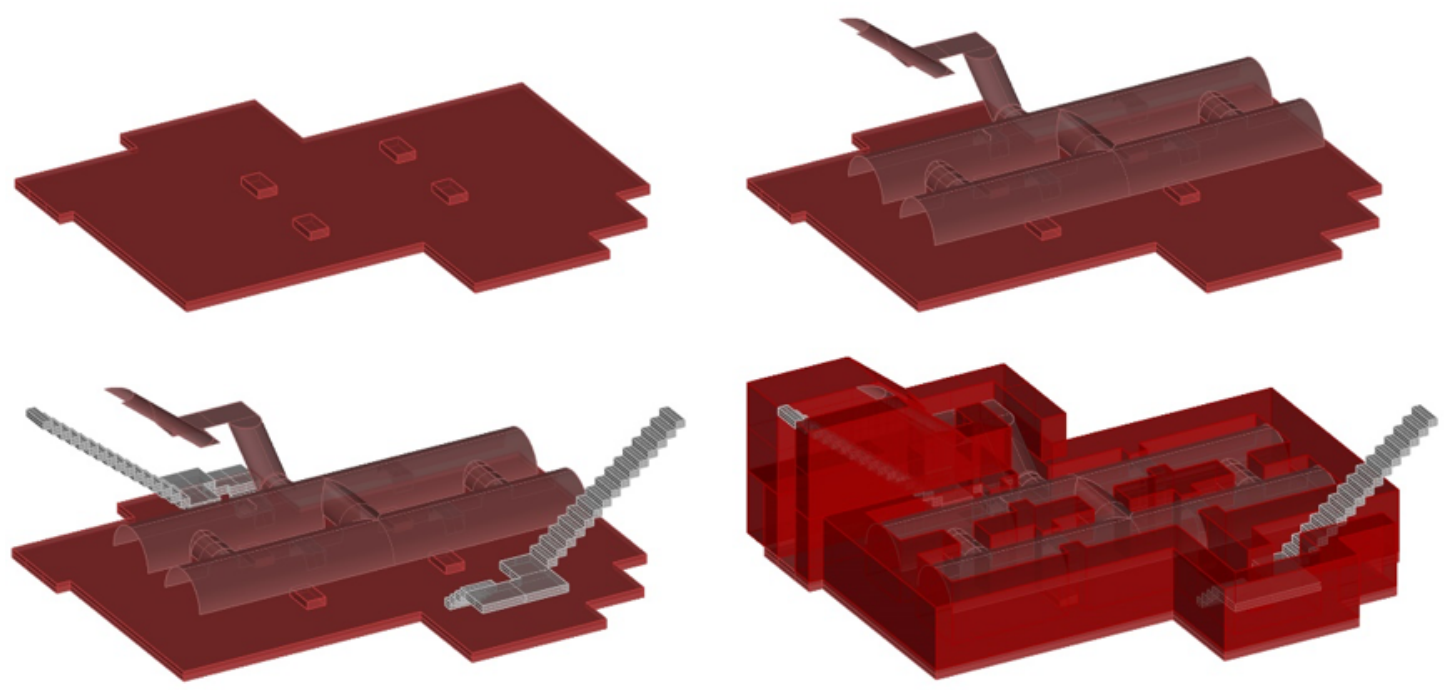

Figure 5. Images of the reconstruction in 3D of the refuge of Plaza Balmis, showing the two longitudinal naves that form three quarters each connected in both directions.

The upper enclosure is made of hollow brick, placed in the form of barrel vaults with lowered arches, ready for tambourine and plastered as shown in the sections in Figures 6 and 7. The upper top of the vaults is made of reinforced concrete, the pavement is made of mass concrete filled with compacted sand. In the original layout of the shelter, the roof contained the doorways to the enclosure and was the only direct contact to the outside, thus achieving greater protection.

The ventilation of the whole structure was through 20 vents placed on the longitudinal axis of the vaults of the galleries. It is a set of ceramic pipes that go from the top of the roof of the shelter to the old roof ridge, which has disappeared. The base of each vent was covered with a layer of plaster that has been almost completely lost.

At present, the shelter has deteriorated due to the high humidity present in the interior (Figure 8) generated by the upper square and the poor ventilation, produced by the only available access.

The square has had many modifications since the shelter was inaugurated in 1938. In 1945, with the Second World War ended and with the passing of the fear of possible attacks on the city, it was decided to demolish the roof for its deterioration, this being the only intervention in its original structure. This public space is located in the centre of Alicante, and despite its small size, has great importance from the 21st century onwards because of its value as a historical route. The surrounding buildings also have great heritage value for the city. In the past it was recognised for its modernist style, represented on the perimeter bench that ran along it, with colourful tiles reminiscent of the work of the Catalan architect Antonio Gaudí. 


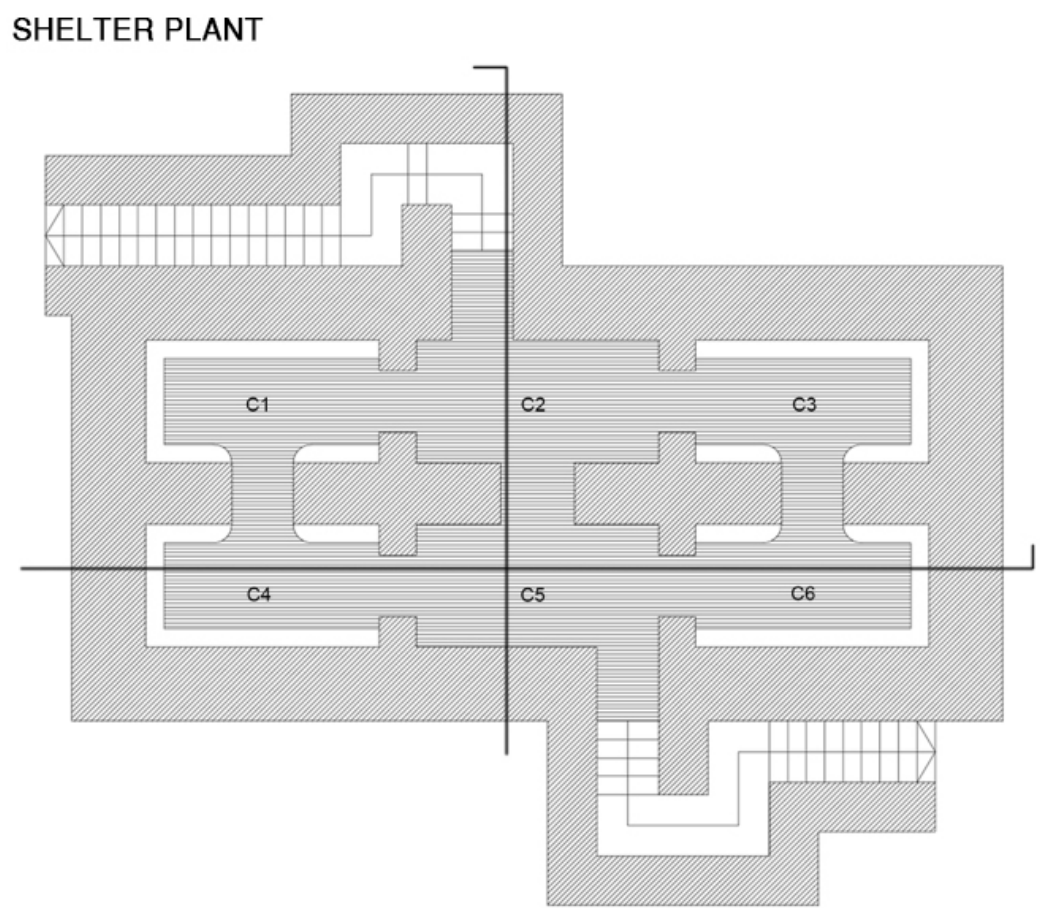

Scale

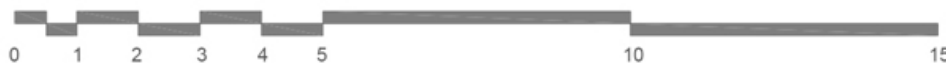

Figure 6. Plant of the refuge of Plaza Balmis with six cells connected in both directions forming two large longitudinal halls.

SECTION 1

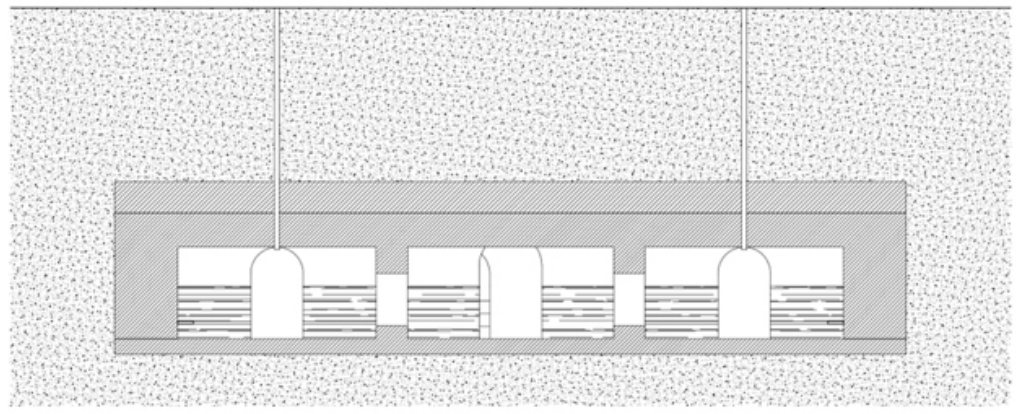

SECTION 2

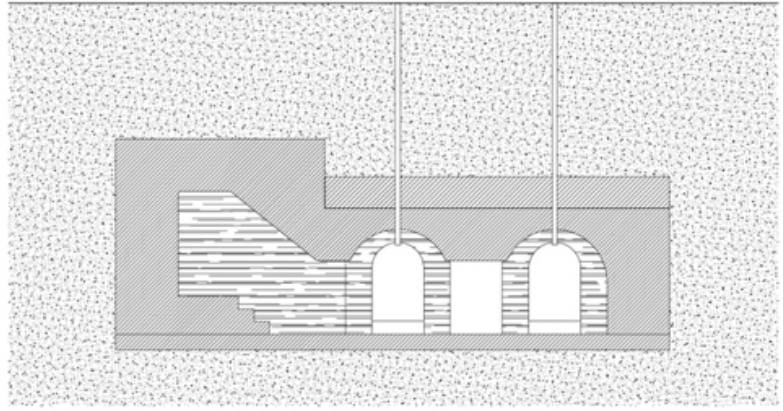

Figure 7. Section of the Plaza Balmis shelter with the three corridors connecting the three spaces that divide the two naves. 


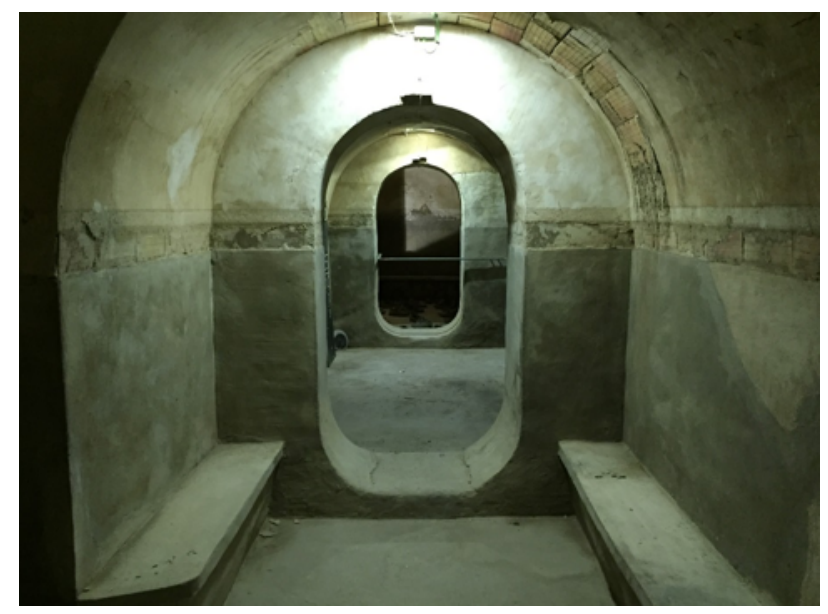

Figure 8. One of the two main halls, where the three cells of this one are distinguished, being the distribution center.

In 2007, the City Council of Alicante plans to remodel the square space in order to modernise it. This is great resistance among the inhabitants and the traders because they consider that the square is in good condition and that there are more important areas needing improvement. For this reason, the modernisation of the square was halted up to 2013 when the project was restarted. During the course of the work, the shelter appears and generates great expectation among the population. Finally, it was decided to respect and value it, and to add an access from Canalejas Street, which is integrated into the pavement and opens with hydraulic elements as seen in the Figure 9.

The building, being underground and poorly ventilated, makes the ground where it is inserted into its material composition. Therefore, the formal composition of the building is not only the different densities concrete with which it was built. The mineralogical composition of the soil means that, although there is little presence of possible radon precursors, this element accumulates inside the building.

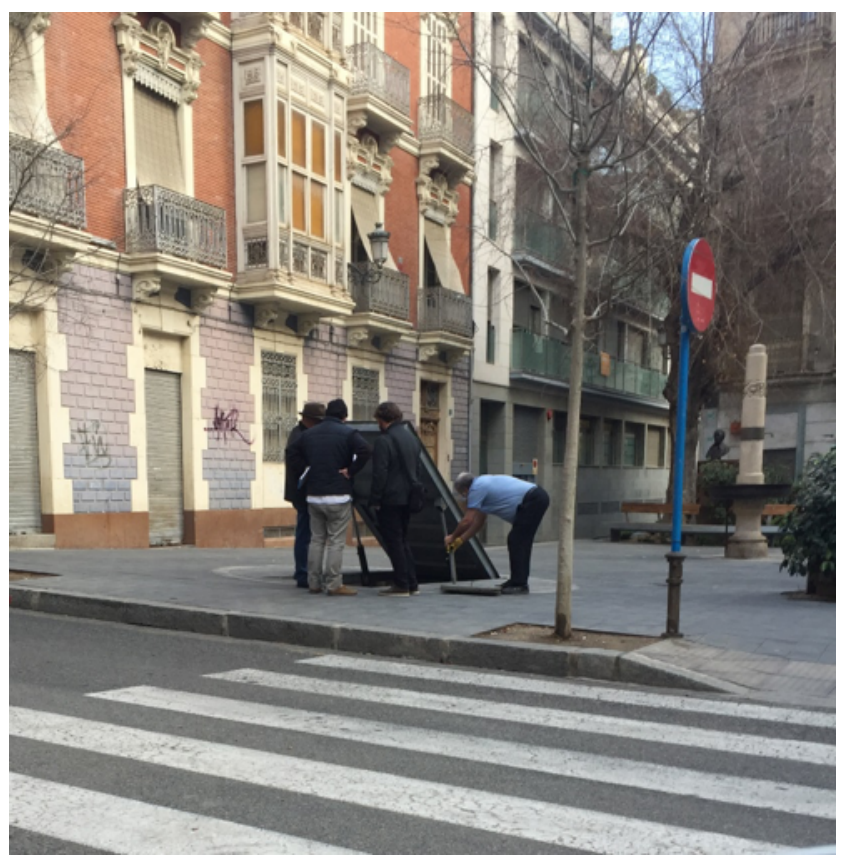

Figure 9. Image showing the opening of the hydraulic access to the Plaza Balmis refuge on Canalejas Street. This entry is being modified by a fixed type for greater security. 


\section{Methodology for Measuring Radon Gas in the Shelter}

The data collection of the shelter of the Plaza del Doctor Balmis was carried out over 22 days, from the 15th of March 2016, and it took place homogeneously throughout the shelter. The measurement zones of the study correspond to the cells, as shown in Table 1 and Figure 10.

Table 1. Association of measurement zones and corresponding cell.

\begin{tabular}{cc}
\hline Zone & Cell \\
\hline Zone 1 & Cell 4 \\
Zone 2 & Cell 1 \\
Zone 3 & Cell 3 \\
Zone 4 & Secondary entrance walled \\
\hline
\end{tabular}

\section{SHELTER PLANT}

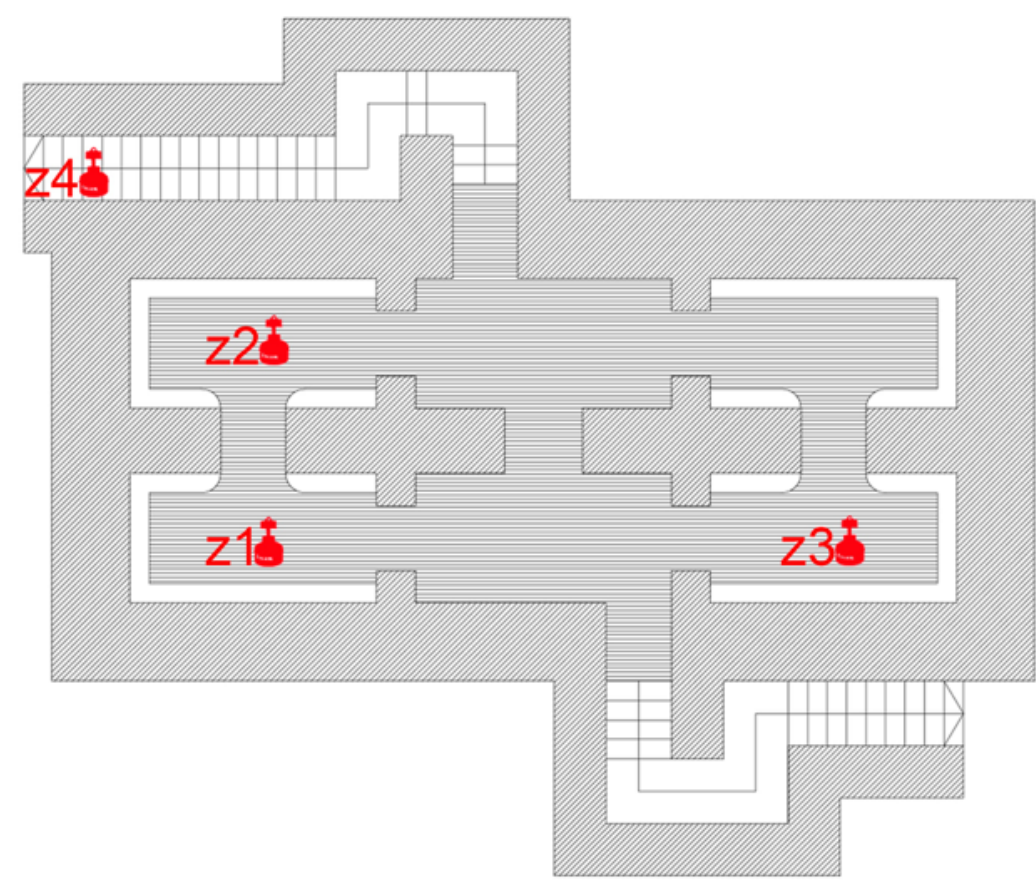

Scale

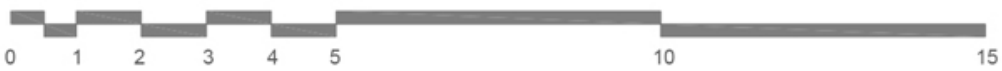

Figure 10. Arrangement of the zones chosen for measurements at the Plaza Balmis refuge.

The plan of the shelter, with its absence of complete partitions, allows all rooms to be connected and to act in a homogeneous way, with ventilation only produced from the access that is available. The walled access generates a bottleneck where the air does not regenerate as much as in the other parts of the shelter. There are also two grilles on the old vents, but they have collapsed and they cause moisture problems.

The radon gas metering system used in the study over the 21 days was the short chamber and short electret of the Eperm System. The short-chamber system is used to monitor radon gas buildup in a short period of time. The measuring tool counts the voltage drop in a charged element, as the presence of radon gas favours the discharge. This discharge is then analyzed in the laboratory and 
related to the space and time of measurement. The plant typology of the site means that all rooms are connected, which makes it possible to foresee that the quantities of radon gas are similar in all of them. The short-short type of camera-electrete measurement is recommended for measuring between 5 and 7 days, but in this case it was impossible to enter the shelter after this time due to the restrictions of those responsible for guarding it. However, the results were not influenced by the longer duration of the measurement as indicated by the specifications of the system used. The climatology during the study was as follows: Rainfall only occurred on 21 March, 4 and 5 April, with $3 \mathrm{~mm}$ accumulated between the three days, which did not greatly affect the ionisation of the site and therefore the rise in the presence of radon gas. Temperatures during the 22 days of the study fluctuated between $26^{\circ} \mathrm{C}$ maximum and $7{ }^{\circ} \mathrm{C}$ minimum reached during the early morning of March 16. Inside the shelter the temperature is usually kept constant, around $16^{\circ} \mathrm{C}$.

\section{Results Analysis}

The results obtained in the different measurements are compared with the $100 \mathrm{~Bq} / \mathrm{m}^{3}$ and $300 \mathrm{~Bq} / \mathrm{m}^{3}$ recommended by the European directive 2013/59/EURATOM of the year 2014 suggested as maximum recommended by the European Commission for Atomic Energy [35] . Therefore, $100 \mathrm{~Bq} / \mathrm{m}^{3}$ is considered as the first threshold from which permanent monitoring of the gas, presence measurement and the level of $300 \mathrm{~Bq} / \mathrm{m}^{3}$ are considered as the threshold from which, mandatory ventilation increase measures must be taken.

The equipment introduced into the Plaza Balmis shelter was placed for 22 days in the different rooms with a unique combination of camera-electrete and short-short. For the representation of the results, a summary Table 2 shows the different measurement zones and the values of the mean environmental concentration obtained from radon gas, in $\mathrm{Bq} / \mathrm{m}^{3}$.

Table 2. Summary mean values of radon concentrations in zones.

\begin{tabular}{cccc}
\hline Zone & Placement & Samples & Mean Radon Concentration $\left(\mathbf{B q} / \mathbf{m}^{\mathbf{3}}\right)$ \\
\hline Zone 1 & Cell 4 & 6 & 216.44 \\
Zone 2 & Cell 2 & 6 & 116.84 \\
Zone 3 & Cell 3 & 6 & 96.98 \\
Zone 4 & Secondary entrance walled & 6 & 224.67 \\
\hline
\end{tabular}

In the shelter, there is a disparity in the results; in Zone 3, $96.98 \mathrm{~Bq} / \mathrm{m}^{3}$ and in Zone 4, corresponding to the secondary entrance, $224.67 \mathrm{~Bq} / \mathrm{m}^{3}$ are reached, that is, more than double the value according to the stay, although both are communicated. This is caused by the distance from each place to the entrance and the different currents generated inside. The main access and the two grilles of the old vents renew the air in the main nucleus of the shelter, but the area of the entrance that is covered with walls does not have such a continuous air supply, an aspect that appears in other similar actions analysed by other authors such as Martín Matarranz or Juan José Llerena [36,37].

Based on the results obtained during the study at the Plaza Balmis shelter, a comparison is made in the different places measured with short chamber and short electrode. As shown in Table 2, the radon gas values in the air reach $224.67 \mathrm{~Bq} / \mathrm{m}^{3}$ at the secondary input (Zone 4 of the measurement).

In the views of the analysed data displayed in the Figure 11, the values obtained in the different measurement zones are below the threshold of $300 \mathrm{~Bq} / \mathrm{m}^{3}$, established within this study as a value above which it is necessary to take corrective ventilation measures. Zones 1 and 4 are the only ones above $100 \mathrm{~Bq} / \mathrm{m}^{3}$, a value above which the presence of radon gas in buildings used by people must be monitored. 

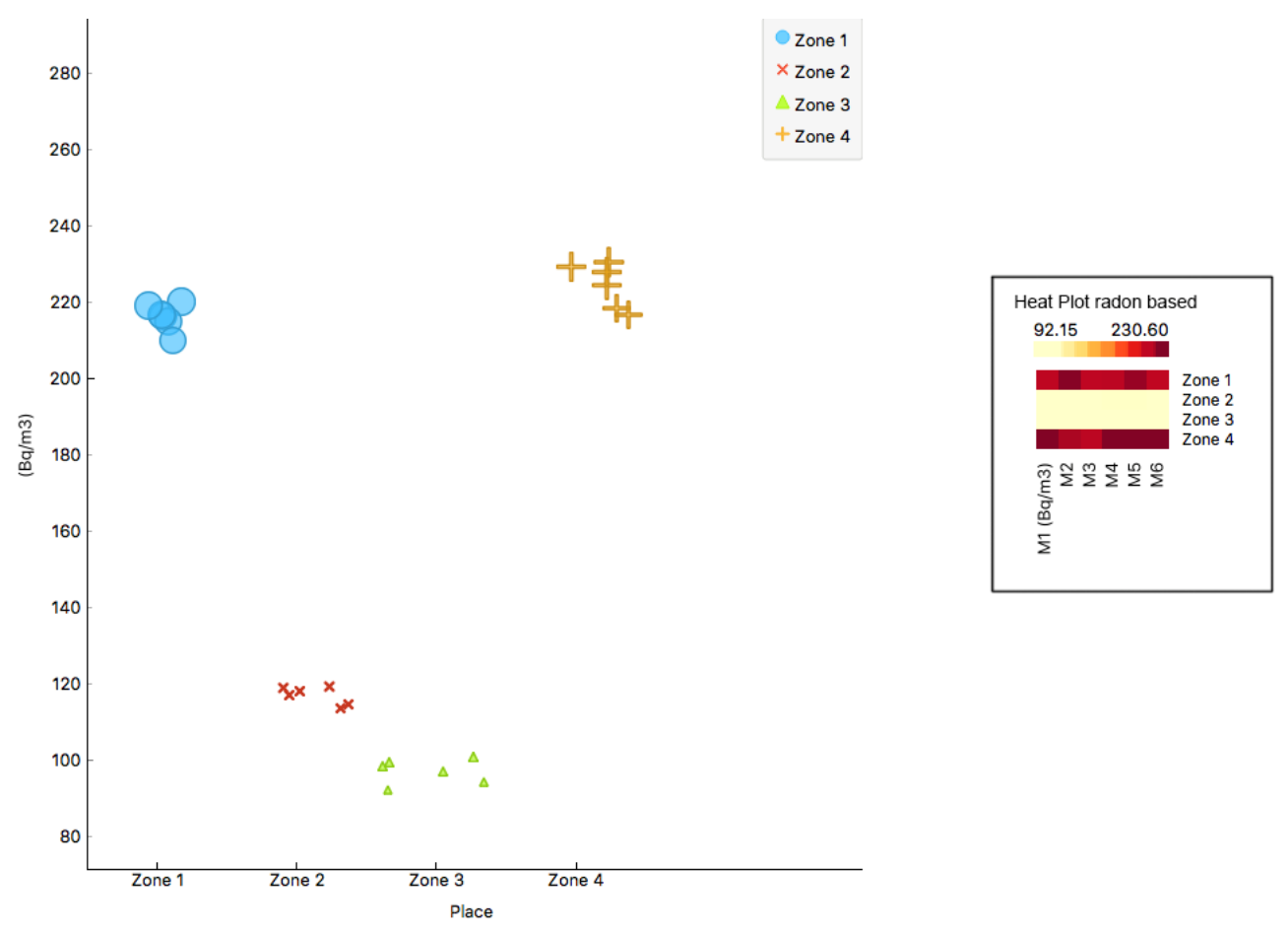

Figure 11. Scatte Plot. Symbol size proportiona and Heat Plot, the different measurements in the coloured areas depending on the presence of radon obtained in each of theml.

As it can be seen in the results representation Figure 12 all measurements are above $100 \mathrm{~Bq} / \mathrm{m}^{3}$. The values of zones 1 and 4 are particularly relevant, with values close to $220 \mathrm{~Bq} / \mathrm{m}^{3}$. The purpose of this research article is to demonstrate the hypothesis that the accumulation of radon gas in buried buildings is greater than that which can occur in unburied buildings, even on clay soils. Clay soils have traditionally been considered of low risk for accumulation of radon. In the early phases of the study and to test the results, measurements were made in unburied defensive buildings, built in concrete and from the same period as the Balmis shelter. In one of these constructions, 24 measurements were taken in four different zones. The results are shown in Figure 13. These values serve as a comparison of the two constructions, since they are above $25 \mathrm{~Bq} / \mathrm{m}^{3}$, in constrast with values higher than $220 \mathrm{~Bq} / \mathrm{m}^{3}$. The shelter of Plaza Balmis presents values five times higher than the similar one not buried, therefore, the non-granitic lands also favour the radon gas accumulation.
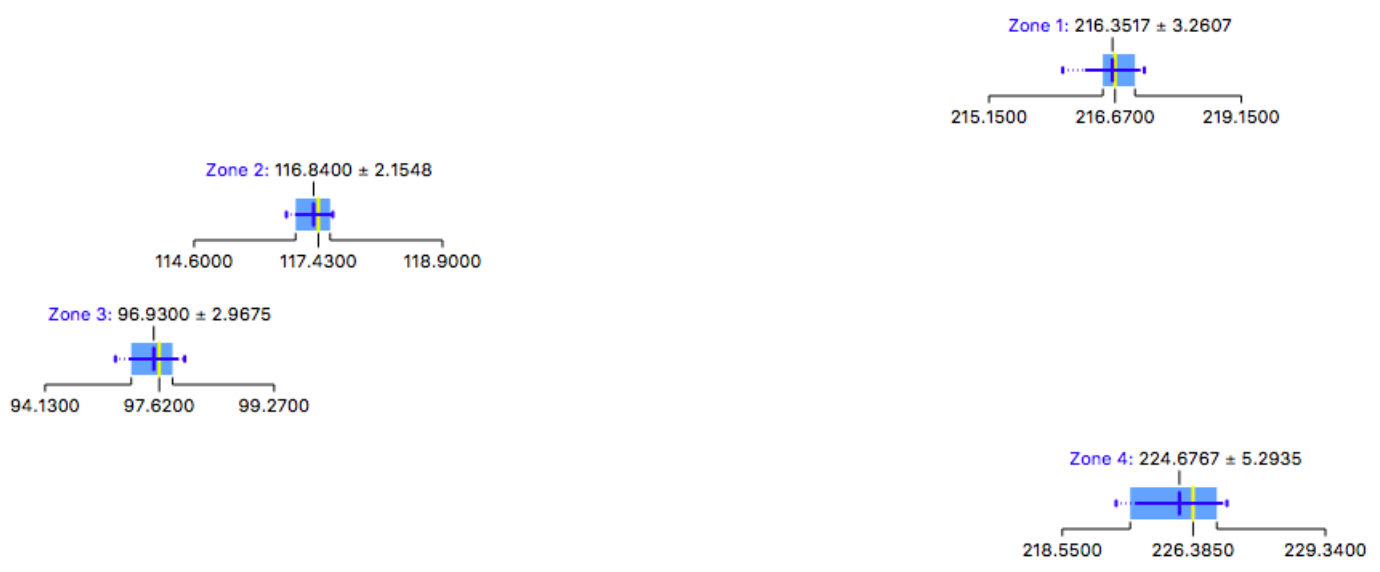

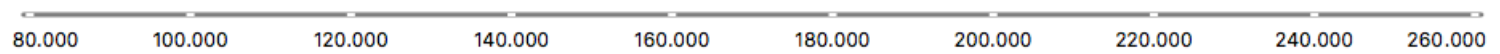

Figure 12. Box Plot zones measures on Plaza Balmis Shelter. 


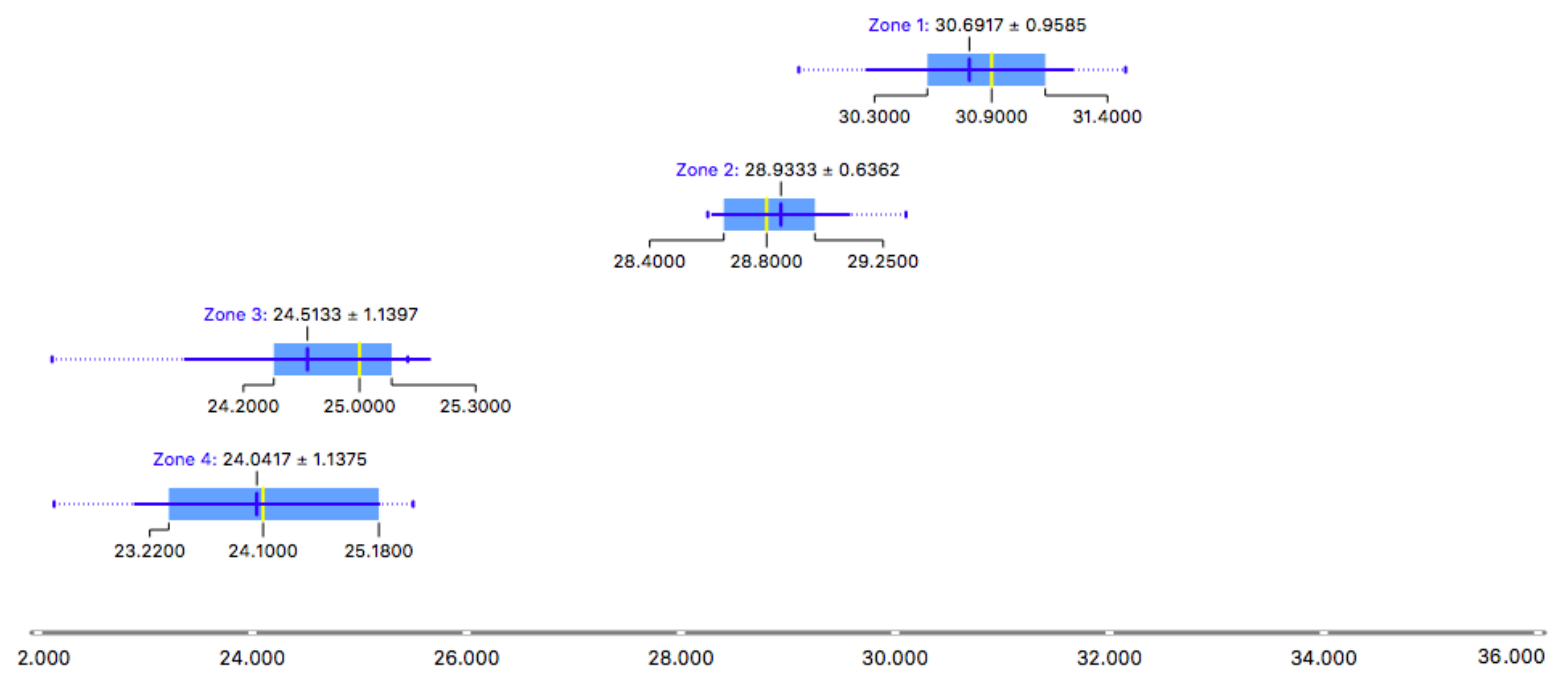

Figure 13. Box Plot zones measures on unburied building.

\section{Conclusions}

The Shelter of Balmis Square of Alicante (Spain) is a defence shelter building was used as a paradigm to demonstrate the presence of radon gas in underground constructions located in clay soils (non-granitic) that are usually considered low risk in terms of the potential presence of radon gas.

The southern Mediterranean coast where Alicante is located is considered a low or very low risk area within the Spanish map of natural radiation (MARNA). This paper has studied the architectural details of the shelter, located in the Balmis Square of Alicante, details not currently available but the City Council intends to incorporate then into the museum's history of the city.

The character of this historical construction, buried under a square in the centre of Alicante, with one of the entrances boarded up, makes for low ventilation inside the shelter. The renewal of produced air is generated only by the available access and by the small grilles of the old vents that are currently collapsed.

The indoor air quality inside the shelter has been studied, taking radon as a very important element to be diagnosed. This allows us to check whether in buildings with old building methods and that are very close to the ground, such as shelters, in this case with little ventilation, radon accumulations are produced.

The compilation of results has been evaluated with the Directive 90/143/EURATOM, where the European Union recommends a target radon gas level in the design phase of $100 \mathrm{~Bq} / \mathrm{m}^{3}$ maximum for newly built buildings and an immediate level of action from $300 \mathrm{~Bq} / \mathrm{m}^{3}$ for interior spaces from which remedial measures should be carried out in existing buildings. Although these values should not be taken as safe when they are less than $100 \mathrm{~Bq} / \mathrm{m}^{3}$, they can be interpreted as a level from which to start paying attention and trying to minimise the values obtained by incorporating a more efficient form of air renewal and establishing more effective constructive methods to accumulate less radon gas.

The shelter forms a uniform volume, with all the cells connected and a single direct air inlet from the outside, coming from the access that is currently in service. With these conditioning factors, the values obtained oscillate between $96.98 \mathrm{~Bq} / \mathrm{m}^{3}$ and $224.67 \mathrm{~Bq} / \mathrm{m}^{3}$ at the walled entrance. These variations are explained by the different flows within the shelter. Only follow-up measurements of the amount of radon present should be taken for this installation, since all measurements are below the established $300 \mathrm{~Bq} / \mathrm{m}^{3} 3$ and almost all measurements are above $100 \mathrm{~Bq} / \mathrm{m}^{3}$. At present, the shelter is unused and these results must be taken into account in the future, when it is opened to the public. Then, the movement inside will be greater air renewal will be improved. 
The predictive maps must be concretised in their application by means of technical building codes, but in most countries, including Spain, the Technical Building Code (CTE) still does not specify the dose of radon that can be contained at most in a building and how to eliminate it.

The research community has already demonstrated that the radon gas is harmful to human health and has become a highly carcinogenic element and therefore, new regulations must incorporate this aspect as a control element. In view of the results presented in this article, it is clear that it is essential that there is compliance with measures (constructive, ventilation, etc.) to limit the presence of radon gas in buildings, especially in enclosed spaces used by people. Radiological studies on exposures to radon in underground workplaces and leisure areas (including public car parks, mines, subways, museums, tourist caves, etc.) should be compulsory in all cases. All this is regardless of the type of soil on which the buildings are built and the type of materials used.

Author Contributions: The work presented here was developed in collaboration among all authors. All authors have contributed to, seen and approved the manuscript.

Acknowledgments: The authors of this paper thanks the University Institute of Water and Environmental Sciences of the University of Alicante for supporting this research.

Conflicts of Interest: The authors declare no conflicts of interest.

\section{References}

1. Cuvier, A.; Panza, F.; Pourcelot, L.; Foissard, B.; Cagnat, X.; Prunier, J.; van Beek, P.; Souhaut, M.; Roux, G.L. Uranium decay daughters from isolated mines: Accumulation and sources. J. Environ. Radioact. 2015, 149, 110-120. [CrossRef] [PubMed]

2. Szabó, K.Z.; Jordan, G.; Horváth, Á.; Szabó, C. Mapping the geogenic radon potential: Methodology and spatial analysis for central Hungary. J. Environ. Radioact. 2014, 129, 107-120. [CrossRef] [PubMed]

3. Collignan, B.; Powaga, E. Impact of ventilation systems and energy savings in a building on the mechanisms governing the indoor radon activity concentration. J. Environ. Radioact. 2017. [CrossRef] [PubMed]

4. Valkovic, V. Radioactivity in the Environment. In Airborne Radioactive Contamination in Inhabited Areas; Elsevier: Amsterdam, The Netherlands, 2009.

5. United Nations Scientific Committee on the Effects of Atomic Radiation. Sources and Effects of Ionizing Radiation: United Nations Scientific Committee on the Effects of Atomic Radiation: UNSCEAR 2000 Report to the General Assembly, with Scientific Annexes; United Nations: New York, NY, USA, 2000.

6. Cristobo, J.J.J.L. Medición de la Concentración de Gas 222Rn en el Interior de Edificios; Departamento de Física de las Partículas de USC: Santiago de Compostela, Spain, 2006; p. 64.

7. Boerma, M.; Sridharan, V.; Mao, X.W.; Nelson, G.A.; Cheema, A.K.; Koturbash, I.; Singh, S.P.; Tackett, A.J.; Hauer-Jensen, M. Effects of ionizing radiation on the heart. Mutat. Res./Rev. Mutat. Res. 2016, 770, 319-327. [CrossRef] [PubMed]

8. Ravanat, J.L.; Douki, T. UV and ionizing radiations induced DNA damage, differences and similarities. Radiat. Phys. Chem. 2016, 128, 92-102. [CrossRef]

9. Amber, I.; O'Donovan, T.S. Natural convection induced by the absorption of solar radiation: A review. Renew. Sustain. Energy Rev. 2018, 82, 3526-3545. [CrossRef]

10. Maestre, C.R.; Yepes, S.C. Radon Gas. Hazardous element for human life really found in the environment. In Proceedings of the 2nd International Conference on Green Materials and Environmental Engineering, Phuket, Thailand, 20-21 December 2015; Editor Atlantis Press: Paris, France, 2015; pp. 60-62.

11. Consejo de Seguridad Nuclear. Dosis de Radiación; Consejo de Seguridad Nuclear: Madrid, Spain, 2010; p. 18.

12. Barbosa-Lorenzo, R.; Ruano-Ravina, A.; Caramés, S.C.; Barros-Dios, J.M. Radón residencial y cáncer de pulmón. Un estudio ecológico en Galicia. Med. Clín. 2015, 144, 304-308. [CrossRef] [PubMed]

13. Nastro, V.; Carnì, D.L.; Vitale, A.; Lamonaca, F.; Vasile, M. Passive and active methods for Radon pollution measurements in historical heritage buildings. Measurement 2018, 114, 526-533. [CrossRef]

14. Bräuner, E.V.; Rasmussen, T.V.; Gunnarsen, L. Variation in residential radon levels in new Danish homes. Indoor Air 2013, 23, 311-317. [CrossRef] [PubMed] 
15. Li, P.; Zhang, R.; Gu, M.; Zheng, G. Uptake of the natural radioactive gas radon by an epiphytic plant. Sci. Total Environ. 2018, 612, 436-441. [CrossRef] [PubMed]

16. Zeeb, H. International Radon Project. Survey On Radon Guidelines, Programmes and Activities; WHO HSE/PHE/RAD: Geneva, Switzerland, 2007; p. 49.

17. NTP 440: Radón en Ambientes Interiores. 1999. Available online: http://insht.es/InshtWeb/Contenidos/ Documentacion/FichasTecnicas/NTP/Ficheros/401a500/ntp_440.pdf (accessed on 17 May 2018).

18. Amgarou, K. Long-Term Measurements of Indoor Radon and Its Progeny in The Presence of Thoron Using Nuclear Track Detectors a Novel Approach; Universitat Autònoma de Barcelona: Bellaterra, Spain, 2003.

19. Cambeses, A.; Garcia-Casco, A.; Scarrow, J.H.; Montero, P.; Pérez-Valera, L.A.; Bea, F. Mineralogical evidence for lamproite magma mixing and storage at mantle depths: Socovos fault lamproites, SE Spain. Lithos 2016, 266-267, 182-201. [CrossRef]

20. Bochicchio, F.; Zunić, Z.S.; Carpentieri, C.; Antignani, S.; Venoso, G.; Carelli, V.; Cordedda, C.; Veselinović, N.; Tollefsen, T.; Bossew, P. Radon in indoor air of primary schools: a systematic survey to evaluate factors affecting radon concentration levels and their variability. Indoor Air 2014, 24, 315-326. [CrossRef] [PubMed]

21. Spengler, J.; Adamkiewicz, G. Indoor Air Pollution: An Old Problem with New Challenges. Int. J. Environ. Res. Public Health 2009, 6, 2880-2882. [CrossRef] [PubMed]

22. Vimercati, L.; Fucilli, F.; Cavone, D.; Maria, L.D.; Birtolo, F.; Ferri, G.; Soleo, L.; Lovreglio, P. Radon Levels in Indoor Environments of the University Hospital in Bari-Apulia Region Southern Italy. Int. J. Environ. Res. Public Health 2018, 15, 694. [CrossRef] [PubMed]

23. Duval, J.S. Use of aerial gamma-ray data to estimate relative amounts of radon in soil gas. In Field Studies of Radon in Rocks, Soils, and Water; DIANE Publishing Company: Collingdale, PA, USA, 1991.

24. Tanner, A.B. Methods of characterization of ground for assessment of indoor radon potential at a site. In Field Studies of Radon in Rocks, Soils, and Water; DIANE Publishing Company: Collingdale, PA, USA, 1991.

25. Borgoni, R.; Tritto, V.; Bigliotto, C.; Bartolo, D.D. A Geostatistical Approach to Assess the Spatial Association between Indoor Radon Concentration, Geological Features and Building Characteristics: The Case of Lombardy, Northern Italy. Int. J. Environ. Res. Public Health 2011, 8, 1420-1440. [CrossRef] [PubMed]

26. Ielsch, G.; Cushing, M.E.; Combes, P.; Cuney, M. Mapping of the geogenic radon potential in France to improve radon risk management: Methodology and first application to region Bourgogne. J. Environ. Radioact. 2010, 101, 813-820. [CrossRef] [PubMed]

27. Ha, M.; Hwang, S.S.; Kang, S.; Park, N.W.; Chang, B.U.; Kim, Y. Geographical Correlations between Indoor Radon Concentration and Risks of Lung Cancer, Non-Hodgkin's Lymphoma, and Leukemia during 1999-2008 in Korea. Int. J. Environ. Res. Public Health 2017, 14, 344. [CrossRef] [PubMed]

28. Kemski, J.; Siehl, A.; Stegemann, R.; Valdivia-Manchego, M. Mapping the geogenic radon potential in Germany. Sci. Total Environ. 2001, 272, 217-230. [CrossRef]

29. Neznal, M.; Matolín, M.; Barnet, I.; Mikšová, J. The New Method for Assessing the Radon Risk of Building Sites; Prace Ceskeho Geologickeho Ustavu; CGS: Prague, Czech Republic, 2004; pp. 7-47.

30. Olaya, M.; Borja, F. El Código Técnico de la Edificación en España (CTE) Medidas Correctoras Destinadas a Frenar la Entrada de Radón en Los Edificios; Investigación de campo como experiencia piloto en España; Instituto Eduardo Torroja: Madrid, Spain, 2007.

31. Francisco, P.W.; Jacobs, D.E.; Targos, L.; Dixon, S.L.; Breysse, J.; Rose, W.; Cali, S. Ventilation, indoor air quality, and health in homes undergoing weatherization. Indoor Air 2017, 27, 463-477. [CrossRef] [PubMed]

32. Cepedal, A.; Fuertes-Fuente, M.; Martín-Izard, A.; García-Nieto, J.; Boiron, M.C. An intrusion-related gold deposit (IRGD) in the NW of Spain, the Linares deposit: Igneous rocks, veins and related alterations, ore features and fluids involved. J. Geochem. Explor. 2013, 124, 101-126. [CrossRef]

33. Loṕez, M.M. La Experiencia Republicana y la Guerra Civil en Alicante; Editor Club Universitario: Rosario, Argentina, 2007; p. 211.

34. Quiertant, P.S.; García, R.M. Refugios antibombardeo dela Guerra Civil Española en el Valle de Henares. In Proceedings of the Actas XII encuentro de Historiadores del valle del Henares, Alcala De Henares, Spain, 25-28 November 2010.

35. EUR-Lex. 90/143/EURATOM: Recomendación de la Comisión EURATOM, de 21 de Febrero de 1990, Relativa a la Protección de la Población Contra Los Peligros de una Exposición al Radón en el Interior de Edificios; European Union (EU): Brussels, Belgium, 1990. 
36. Scientifique et Technique de la Construction Centre. Le Radon Dans les Habitations; Scientifique et Technique de la Construction Centre: Bruxelles, Belgium, 1999.

37. Matarranz, J.L.M. Concentraciones de Radón en Viviendas Españolas; Consejo de Seguridad Nuclear: Madrid, Spain, 2004; p. 107. 